\title{
Occurrence and molecular characterization of Bartonella spp. and hemoplasmas in neotropical primates from Brazilian Amazon
}

\author{
Letícia Bonato, Mayra Araguaia Pereira Figueiredo, Luiz Ricardo Gonçalves, \\ Rosangela Zacarias Machado, Marcos Rogério André*
}

Laboratório de Imunoparasitologia, Departamento de Patologia Veterinária, Faculdade de Ciências Agrárias e Veterinárias/Universidade Estadual Paulista (FCAV/UNESP), Jaboticabal, SP, Brazil

\section{A R T I C L E I N F O}

\section{Article history:}

Received 22 July 2015

Received in revised form 31 August 2015

Accepted 1 September 2015

\section{Keywords:}

Bartonella spp.

Hemotropic mycoplasmas

Monkeys

Amazon

Brazil

\begin{abstract}
A B S T R A C T
Little is known about the prevalence and genetic diversity of Bartonella spp. and hemoplasmas in nonhuman primates (NHP). The present study aimed to investigate the occurrence of and assess the phylogenetic position of Bartonella spp. and hemoplasma species infecting neotropical NHP from Brazilian Amazon. From 2009 to 2013, a total of 98 blood samples from NHP belonging to the Family Cebidae were collected in the island of São Luís, state of Maranhão, of which 87 NHP were from Wild Animal Screening Center (CETAS) in the municipality of São Luís, and 11 (9 Sapajus sp. and 2 Saimiri sciureus) were from NHP caught in the Sítio Aguahy Private Reserve. DNA samples were screened by previously described PCR protocols for amplifying Bartonella spp. and Mycoplasma spp. based on nuoG, gltA and 16S rRNA genes, respectively. Purified amplicons were submitted to sequencing and phylogenetic analysis. Bacteremia with one or more Bartonella spp. was not detected in NHP. Conversely, 35 NHP were PCR positive to Mycoplasma spp. The Blastn analysis of seven positive randomly selected sequencing products showed percentage of identity ranging from $95 \%$ to $99 \%$ with other primates hemoplasmas. The Maximum Likelihood phylogenetic analysis based on a $1510 \mathrm{bp}$ of $16 \mathrm{~S}$ rRNA gene showed the presence of two distinct clusters, positioned within Mycoplasma haemofelis and Mycoplasma suis groups. The phylogenetic assessment suggests the presence of a novel hemoplasma species in NHP from the Brazilian Amazon.
\end{abstract}

(C) 2015 Elsevier Ltd. All rights reserved.

\section{Introduction}

Arthropod-borne pathogens are important cause of morbidity and mortality in a wide spectrum of animal species, including humans $[1,2]$. Because $75 \%$ of emerging pathogens cause disease in humans and animals, a One Health approach to zoonotic infections is needed to correctly address animal and human health [1]. In this context, hemotropic mycoplasmas (also known as hemoplasmas) and Bartonella spp. emerge as important arthropod-borne pathogens that impact humans and animals' health [1,3]. While hemoplasmas are obligate bacteria that attach to red cells' surface, Bartonella spp. are facultative intracellular bacteria that also cause prolonged intraerythrocytic bacteremia in a wide variety of wild and domestic animals, including humans [4-6].

\footnotetext{
* Corresponding author at: Laboratório de Imunoparasitologia, Departamento de Patologia Veterinária, Faculdade de Ciências Agrárias e Veterinárias Júlio de Mesquita Filho (UNESP), Campus de Jaboticabal, Via de Acesso Prof. Paulo Donato Castellane, s/n, Zona Rural, CEP: 14884-900, Jaboticabal, São Paulo, Brazil.

E-mail address: marcos_andre@fcav.unesp.br (M.R. André).
}

There is a limited number of reports on the occurrence of Bartonella and hemoplasmas on nonhuman primates (NHP). Bartonella quintana has been isolated from blood culture or PCR detected in a cynomolgus monkey (Macaca fascicularis) imported by the USA from the South East Asia [7], and from captive Rhesus and cynomolgus monkeys in China $[8,9]$.

Among NHP, hemotropic mycoplasma infection has been reported in experimental and breeding colony monkeys, such as squirrel (Saimiri sciureus), cynomolgus (M. fascicularis) and owl (Aotus trivirgatus) monkeys [10-13] in French Guiana, the United States of America and the United Kingdom, respectively. In two cases, molecular studies allowed the description of new hemoplasma species namely 'Candidatus Mycoplasma kahanei' [14] and 'Candidatus Mycoplasma aoti' [13]. In Brazil, Mycoplasma spp. closely related to 'Candidatus Mycoplasma kahanei' was detected in an adult female free-ranging black howler monkey (Alouatta caraya) in the state of Parana, Brazil [15].

The present study aimed to investigate the occurrence of and assess the phylogenetic relationship of Bartonella spp. and hemoplasma species infecting neotropical primates from the island of São Luís, state of Maranhão, northeastern Brazil. 


\section{Material and methods}

\subsection{Study areas and blood samples from NHP}

The Legal Amazon Region comprises the Brazilian states of Acre, Amapá, Amazonas, Pará, Rondônia, Roraima, Tocantins, Mato Grosso and Maranhão. The present work was carried out in two municipalities which are part of the island of São Luís, state of Maranhão, northeastern Brazil (Fig. 1 - Capture sites - Map of Maranhão State showing the Island of São Luís where NHP blood samples were collected (MapInfo Professional 7.5 SCP). From 2009 to 2013, a total of 112 blood samples from NHP belonging to the Family Cebidae [16] were collected, of which 98 NHP were from Wild Animal Screening Center (CETAS) ( $2^{\circ} 56^{\prime} 80^{\prime \prime}$ S, 44 $21^{\prime} 01^{\prime \prime} \mathrm{W}$ ), which is located in the urban area of the municipality of São Luís, and 14 (11 Sapajus sp. and 3 S. sciureus) were from NHP caught in the Sítio Aguahy Private Reserve ( $\left.2^{\circ} 38^{\prime} 76^{\prime \prime} \mathrm{S}, 44^{\circ} 08^{\prime} 22^{\prime \prime} \mathrm{W}\right)$, which is located in the rural area of the municipality of São José de Ribamar, an area of environmental preservation named Guarapiranga, that has less than 300 inhabitants [17]. The activities were approved by the Animals Ethics Committee of FCAV-UNESP Jaboticabal (Protocol No. 020091/09) and by the Chico Mendes Biodiversity Institute (ICMBio) (license No. 23078-1).

Blood sampling was performed through venipuncture of the jugular or femoral veins of the NHP, which had previously been anesthetized using a combination of zolazepam hydrochloride and tiletamine hydrochloride, according to each species. The samples collected were placed in Vacutainer ${ }^{\circledR}$ tubes containing EDTA [17].

\subsection{PCR assays}

\subsubsection{DNA extraction}

DNA was extracted from $200 \mu \mathrm{L}$ of each NHP whole blood sample using the DNeasy ${ }^{\circledR}$ Blood \& Tissue Kit (Qiagen, Valencia,
California, USA), according to manufacturer's instructions. DNA concentration and absorbance ratio $(260 / 280) \mathrm{nm}$ were measured using a spectrophotometer (Nanodrop, Thermo Scientific, Waltham, MA, USA). Microtubes containing ultra-pure sterile water were used as negative extraction controls, intercalated between each series of twenty NHP blood samples and submitted to DNA extraction.

\subsubsection{Internal control PCR}

In order to discard the presence of PCR inhibitors, each sample of blood extracted DNA was used as a template in an internal control PCR targeting the mammal GAPDH gene [18]. Five microliters of DNA were used as a template in $25 \mu \mathrm{L}$ reaction mixtures containing 10X PCR buffer, $1.0 \mathrm{mM} \mathrm{MgCl} 2,0.6 \mathrm{mM}$ deoxynucleotide triphosphate (dNTPs) mixture, 1.5 U Taq DNA Polymerase (Life Technologies, Carlsbad, CA, USA), and $0.5 \mu \mathrm{M}$ of GAPDH-F (5'-CCTTCATTGACCTCAACTACAT-3') and GAPDH-R (5'CCAAAGTTGTCATGGATGACC- $3^{\prime}$ ) primers. PCR amplifications were performed at $94^{\circ} \mathrm{C}$ for $5 \mathrm{~min}$ followed by 35 repetitive cycles of $94{ }^{\circ} \mathrm{C}$ for $30 \mathrm{~s}, 50^{\circ} \mathrm{C}$ for $30 \mathrm{~s}$, and $72{ }^{\circ} \mathrm{C}$ for $1 \mathrm{~min}$, followed by a final extension at $72^{\circ} \mathrm{C}$ for $5 \mathrm{~min}$. Positive samples to above described internal control PCR protocol were subsequently submitted to quantitative real time PCR (qPCR targeting nuoG gene) and conventional PCR (CPCR targeting gltA gene) for Bartonella spp. and CPCR assays for Mycoplasma spp. targeting 16S rRNA and RNaseP genes as described below.

\subsection{3. $q P C R$ and $c P C R$ assays for Bartonella spp}

qPCR reactions for Bartonella spp. targeting nuoG gene were performed using the $10 \mu \mathrm{L}$ PCR mixtures contained $5 \mu \mathrm{L}$ of Go Taq ${ }^{\circledR}$ Probe qPCR Master Mix, dTTP (Promega) with a final concentration of $1.2 \mu \mathrm{M}$ of each primer (F-Bart [5'-CAATCTTCTTTTGCTTCACC$\left.3^{\prime}\right]$ and R-Bart [5'-TCAGGGCTTTATGTGAATAC-3'] and hydrolysis probe (TexasRed-5'-TTYGTCATTTGAACACG-3'[BHQ2a-Q $] 3^{\prime}$ ) and

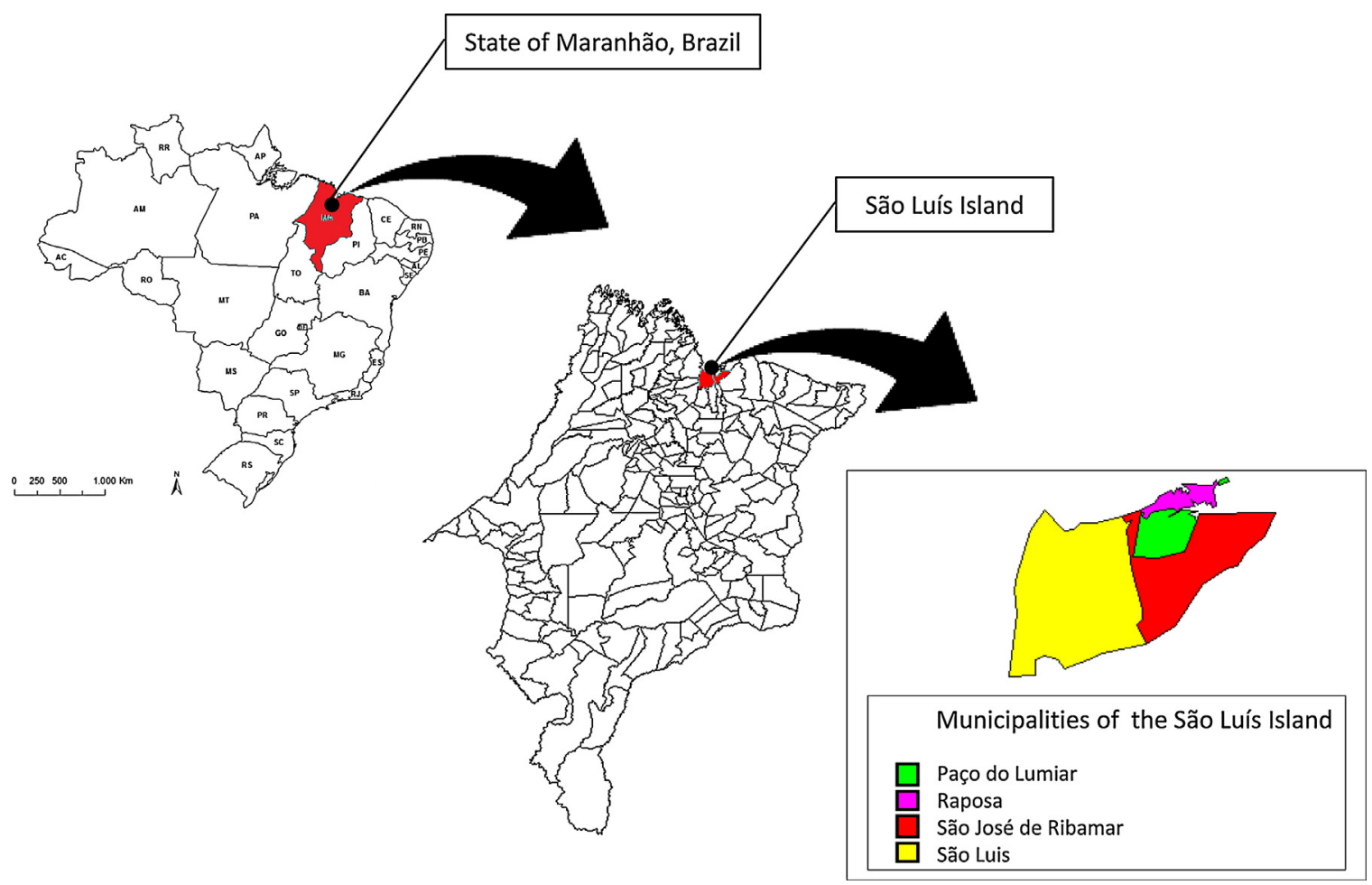

Fig. 1. Capture sites. Map of Maranhão State showing the Island of São Luís where nonhuman primates blood samples were collected (MapInfo Professional 7.5 SCP). 
$1 \mu \mathrm{L}$ of DNA sample [19]. PCR amplifications were conducted in Low-Profile Multiplate ${ }^{\mathrm{TM}}$ Unskirted PCR Plates (BioRad, Hercules, CA, USA) using CFX96 Thermal Cycler (BioRad, Hercules, CA, USA). The amplification conditions were $95^{\circ} \mathrm{C}$ for $3 \mathrm{~min}$ followed by 40 cycles of $95^{\circ} \mathrm{C}$ for $10 \mathrm{~min}$ and $52.8^{\circ} \mathrm{C}$ for $30 \mathrm{~s}$. The qPCR was performed following the Minimum Information for Publication of Quantitative Real-Time PCR Experiments (MIQE) [20]. Amplification efficiency $(E)$ was calculated from the slope of the standard curve in each run using the following formula $\left(E=10^{-1 / \text { slope }}\right)$. Copy numbers were estimated using 10 -fold serial dilutions of pIDTSMART plasmids (Integrated DNA Technologies, Coralville, IA, USA) encoding nuoG $B$. henselae sequence (insert containing $83 \mathrm{bp}$ ). The number of plasmid copies was determined according to the formula $(\mathrm{Xg} / \mu \mathrm{L}$ DNA/[plasmid length in $b p \times 660]) \times 6.022 \times 10^{23} \times$ plasmid copies $/ \mu$ L. Plasmids (Integrated DNA Technologies, Coralville, IA, USA) encoding nuoG B. henselae sequence were used as positive controls.

Additionally, a previously described PCR protocol based on gltA gene was utilized to amplify Bartonella spp. DNA, using the combined primers namely BhCS.1137 (AATGCAAAAAGAACAGTAAACA) [21] and CSH1f (GCGAATGAAGCGTGCCTAAA) [22] (fragment of $\sim 350 \mathrm{bp}$ ). Five microliters of DNA were used as a template in $25 \mu \mathrm{L}$ reaction mixtures containing $10 \mathrm{X}$ PCR buffer, $1.0 \mathrm{mM} \mathrm{MgCl}_{2}$, $0.8 \mathrm{mM}$ deoxynucleotide triphosphate (dNTPs) mixture, $1.0 \mathrm{U}$ Taq DNA Polymerase (Life Technologies, Carlsbad, CA, USA) and $0.5 \mu \mathrm{M}$ of each primer. B. henselae DNA (GenBank accession number KC331015) obtained from a naturally infected cat [23] was used as positive control. Ultra-pure sterile water was used as negative control in all PCR assays described above. PCR amplifications were performed by an initial cycle of $94^{\circ} \mathrm{C}$ for 5 min followed by 35 cycles of $94^{\circ} \mathrm{C}$ for $30 \mathrm{~s}, 54^{\circ} \mathrm{C}$ for $30 \mathrm{~s}$ and $72^{\circ} \mathrm{C}$ for $1 \mathrm{~min}$, and an extension final by $72^{\circ} \mathrm{C}$ for $5 \mathrm{~min}$.

\subsection{4. cPCR assays for Mycoplasma spp.}

Previously described PCR protocols based on 16S rRNA gene were utilized to amplify Mycoplasma spp. DNA, using two sets of primers, namely HemMycop16S-41s (5'-GYATGCMTAAYACAT GCAAGTCGARCG-3') and HemMyco16S-938as (5'-CTCCACCACTT GTTCAGGTCCCCGTC-3') (fragment of $\sim 800 \mathrm{bp}$ ), and HemMycop16S-322s (5'-GCCCATATTCCTACGGGAAGCAGCAGT-3') and HemMycop16S-1420as (5'-GTTTGACGGGCGGTGTGTACAAGACC$3^{\prime}$ ) (fragment of $\sim 800 \mathrm{bp}$ ) [24]. Five microliters of DNA were used as a template in $25 \mu \mathrm{L}$ reaction mixtures containing $10 \mathrm{X}$ PCR buffer, $1.0 \mathrm{mM} \mathrm{MgCl} 2,0.8 \mathrm{mM}$ deoxynucleotide triphosphate (dNTPs) mixture, 1.5U Taq DNA Polymerase (Life Technologies, Carlsbad, CA, USA) and $0.3 \mu \mathrm{M}$ of each primer. Mycoplasma haemofelis DNA (Genbank accession number KJ135315) obtained from a naturally infected cat [23] was used as positive control. Ultra-pure sterile water was used as negative control in all PCR assays described above. PCR amplifications were performed at $94{ }^{\circ} \mathrm{C}$ for $2 \mathrm{~min}$ followed by 55 repetitive cycles of $94^{\circ} \mathrm{C}$ for $15 \mathrm{~s}$, $68^{\circ} \mathrm{C}$ for $15 \mathrm{~s}$ and $72^{\circ} \mathrm{C}$ for $18 \mathrm{~s}$, followed by a final extension at $72^{\circ} \mathrm{C}$ for $1 \mathrm{~min}$. 16S rRNA Mycoplasma spp.-positive samples were additionally submitted to RNaseP gene-Mycoplasma spp. (165 bp) PCR assay using the oligonucleotides HemoMyco RNaseP30s (5'GATKGTGYGAGYATATAAAAAATAAARCTCRAC-3') and HemoMyco RNaseP200as (5'-GMGGRGTTTACCGCGTTTCAC-3'). The conditions of amplification were the same as described above, except for the annealing temperature $\left(59^{\circ} \mathrm{C}\right)$ [24]. In order to prevent PCR contamination, DNA extraction, reaction setup, PCR amplification and electrophoresis were performed in separated rooms.

\subsection{Phylogenetic analysis}

The products derived from amplicons obtained from each primer set ( $1300 \mathrm{bp}$ for $16 \mathrm{~S}$ rRNA of Mycoplasma spp., with an overlap of $600 \mathrm{bp}$ to improve the identification of species detected) were purified using Silica Bead DNA Gel Extraction Kit (Fermentas, São Paulo, SP, Brazil). Purified amplified DNA fragments from positive samples were submitted to sequence confirmation in an automatic sequencer (ABI Prism 310 Genetic Analyser Applied Byosystem/Perkin Elmer, Waltham, MA, USA). Consensus sequences were obtained through the analysis of the sense and antisense sequences using the CAP3 program (http://mobyle. pasteur.fr/cgi-bin/MobylePortal/portal.py). Primer sequences were trimmed from the consensus sequences prior Blastn analysis. Comparisons with sequences deposited in GenBank were done using the basic local alignment search tool (BLASTn) [25]. The sequences were aligned with sequences published in GenBank using Clustal/W [26] and manually adjusted in Bioedit v. 7.0.5.3 (Carlsbad, CA, USA) [27]. Phylogenetic inference based on maximum likelihood criterion (ML), was inferred with RAxML-HPC BlackBox 7.6.3 [28] through the CIPRES Science Gateway [29]. Akaike information criterion was used in Mega 5.05 to identify the most appropriate model of nucleotide substitution. GTRGAMMA model was chosen as the most appropriate for the Maximum Likelihood analysis of the $16 \mathrm{~S}$ rDNA alignment.

\section{Results}

Out of 112 NHP blood samples analyzed, 98 were positive to internal control (GAPDH gene) (Median DNA concentration $=12.6 \mathrm{ng} / \mathrm{uL} ; \mathrm{SD}$ [standard deviation] $\pm 10.3 ; 260 / 280$ ration $=2.6 ; \mathrm{SD} \pm 0.78$ ). All negative samples to GAPDH gene-PCR were excluded from subsequent analysis. Bacteremia with one or more Bartonella spp. was not detected in NHP in both qPCR (nuOG gene; efficiency of qPCR reactions targeting nuoG gene: 90.9\%, $r^{2}=0.999 ; 91.3 \%, r^{2}=0.998$; and $\left.90.9 \%, r^{2}=0.999\right)$ and $\mathrm{CPCR}$ (gltA gene) assays. The analytical sensitivity per qPCR reaction was 10 copies/ $\mu$ L. Among 98 NHP blood samples analyzed, 35 (35.7\%) were PCR positive to Mycoplasma spp. (Table 1), detected from the following host species: Sapajus apella, S. sciureus and Saguinus midas niger. Unfortunately, all positive samples to $16 \mathrm{~S}$ rRNA gene that were tested by the RNaseP gene PCR yielded bands of weak intensity which precluded sequencing efforts of these fragments.

The Blastn analysis indicated that amplified sequences (GenBank accession numbers KT314160, KT314161, KT314162, KT314163, KT314164, KT314165, KT314166) demonstrated percentage of identity ranging from $95 \%$ to $99 \%$ with other NHP hemoplasmas ('Candidatus Mycoplasma haemomacaque', and 'Candidatus Mycoplasma kahanei') sequences deposited in Genbank (Table 2). The sequences obtained were different from the positive control used in the PCR reactions ( $M$. haemofelis - Genbank accession number KJ135315).

The ML phylogenetic analysis based on a fragment of $1510 \mathrm{bp}$ (after the alignment by Bioedit) of 16S rRNA gene of seven positive

\section{Table 1}

Number of neotropical primates tested positive by hemoplasmas PCR, according to species, capture sites, and gender.

\begin{tabular}{|c|c|c|c|}
\hline Scientific name & Capture sites & Gender & $\begin{array}{l}\text { Number of animals } \\
\text { positive for hemoplasma } \\
\text { cPCR (16S rRNA) }\end{array}$ \\
\hline Aotus infulatus & CETAS & $1 \mathrm{~F}$ & - \\
\hline Sapajus sp. & $\begin{array}{l}\text { CETAS and Sítio } \\
\text { Aguahy }\end{array}$ & $38 \mathrm{M} / 27 \mathrm{~F}$ & 29 \\
\hline Callithrix jacchus & CETAS & $6 \mathrm{M} / 3 \mathrm{~F}$ & - \\
\hline Saimiri sciureus & $\begin{array}{l}\text { CETAS and Sítio } \\
\text { Aguahy }\end{array}$ & $12 \mathrm{M} / 4 \mathrm{~F}$ & 04 \\
\hline $\begin{array}{l}\text { Saguinus midas } \\
\text { niger }\end{array}$ & CETAS & $3 \mathrm{M} / 4 \mathrm{~F}$ & 02 \\
\hline Total & & 98 & 35 \\
\hline
\end{tabular}

$\mathrm{F}=$ female; $\mathrm{M}=$ male. 
Table 2

Closest identity percentage (Blastn) between NHP hemoplasma 16S RNA sequences detected in Brazil and other primate hemoplasma sequences previously submitted to GenBank from others regions of the world.

\begin{tabular}{|c|c|c|c|}
\hline \multirow[t]{2}{*}{ NHP sampled } & \multicolumn{3}{|c|}{ Percentage of identity (\%) by Blast analysis } \\
\hline & $\begin{array}{l}\text { 'C. M. haemo- } \\
\text { macaque’ } \\
(\text { KC512401) }\end{array}$ & $\begin{array}{l}\text { ‘C. M. haemo- } \\
\text { macaque’ } \\
\text { (AB820288) }\end{array}$ & $\begin{array}{l}\text { ‘C. M. kahanei’ } \\
\text { (AF338269) }\end{array}$ \\
\hline Sapajus apellaa & 95 & 95 & - \\
\hline Sapajus apella (C) & 95 & 95 & - \\
\hline Sapajus apella (C) & 95 & 95 & - \\
\hline Sapajus apella (C) & 95 & 95 & - \\
\hline Sapajus apella (C) & 96 & 97 & - \\
\hline Saimiri sciureus & - & - & 99 \\
\hline Saimiri sciureus ${ }^{\mathrm{a}}$ & - & - & 99 \\
\hline
\end{tabular}

\section{C: CETAS.}

a Free-ranging NHP.

randomly selected samples showed the presence of two distinct clusters (Fig. 2). The sequences belonging to cluster-1 were positioned within $M$. haemofelis group and showed a strong separation from 'Candidatus Mycoplasma haemomacaque' detected in primates in USA and Japan supported by a high bootstrap value
(99). On the other hand, the sequences belonging to cluster-2 were positioned within Mycoplasma suis group, clustering together (bootstrap value of 100) and showing a high percentage of identity (99\%) with 'Candidatus Mycoplasma kahanei', which was detected in S. sciureus in the USA.

\section{Discussion}

There is a limited number of reports on the occurrence and genetic diversity of Bartonella spp. and hemoplasmas in NHP around the world. Experimental inoculation of rhesus monkeys with $B$. quintana isolated from human patients resulted in chronic bacteremia [30,31] suggesting the possibility that NHP may be susceptible to the infection by Bartonella species acquired from humans or from other monkeys. Later, studies have shown the presence of different genotypes of $B$. quintana in NHP $[7,8]$. An occurrence of $30.7 \%$ for B. quintana has been reported in NHP (Macaca mulatta and M. fascicularis) maintained in Primatology Centers in China, using blood culture and/or PCR techniques [9]. In the present study, bacteremia with one or more Bartonella spp. was not detected in NHP. If Bartonella infection in NHP follows the same pathogenicity as in humans, one would expect that asymptomatic

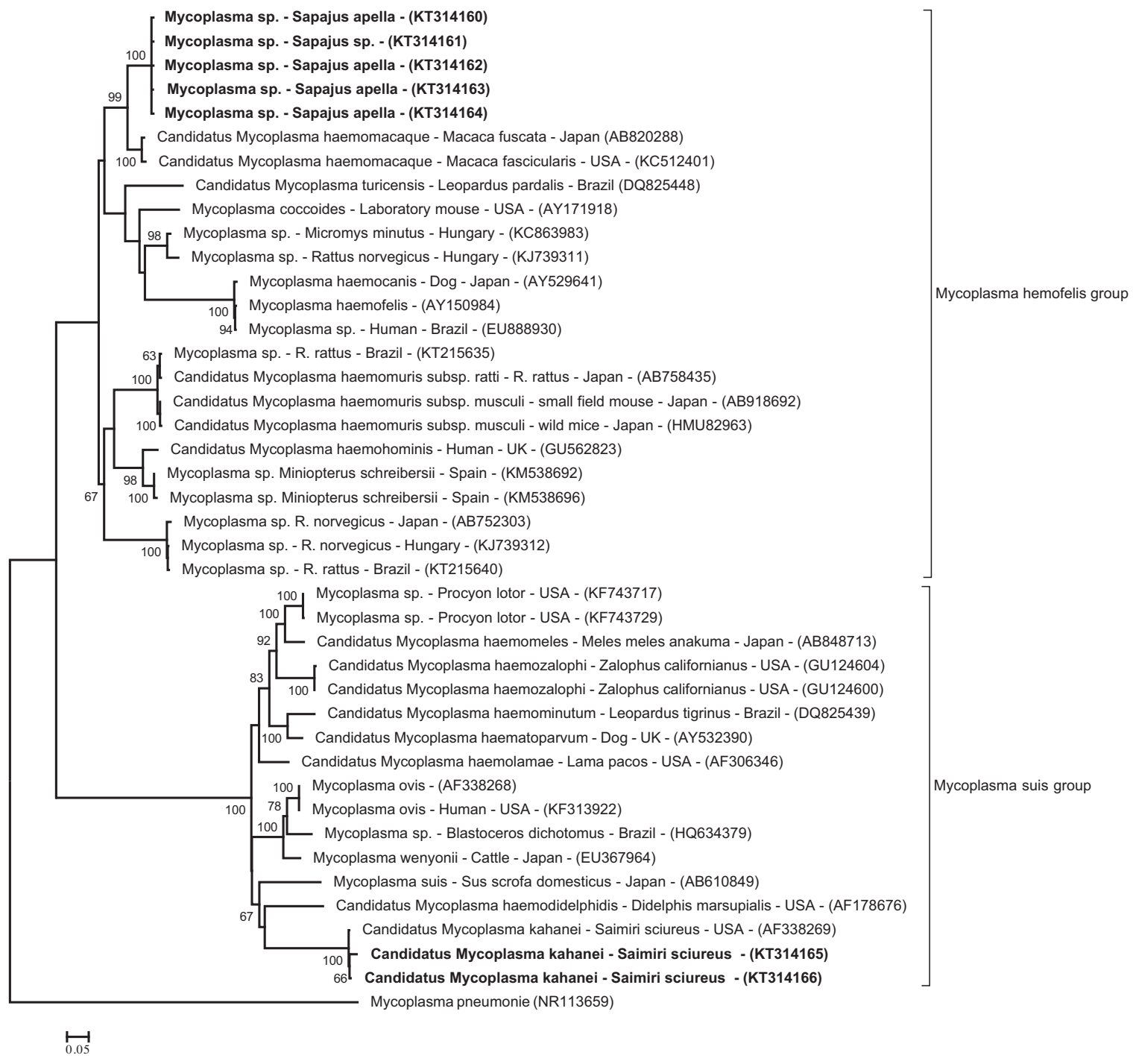

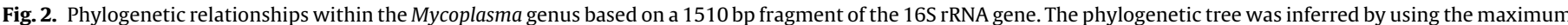

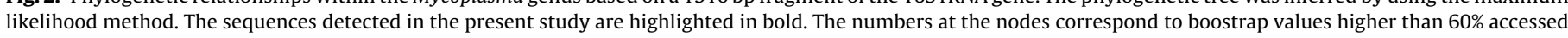
with 1.000 replicates. Mycoplasma pneumoniae was used as outgroup. 
NHP would have very low bacteremia [32], probably below the limit of detection of the PCR assay. Bartonella bacteremia is more readily documented in a primary reservoir species, such as cats or rodents [32] and might occur less frequently or to a much lower level in accidental hosts, such as humans or primates. In humans, the average bacterial levels in blood are 1-10 genome copies/ $\mu 1$, compared to the $10^{5}$ to $10^{6}$ copies/ $\mu$ l often found in cats [32]. In a recent study in blood donors in Brazil, only $3 \%$ of subjects were bacteremic for Bartonella spp. when tested by a combined enrichment liquid culture step prior PCR testing [33]. Further studies aiming to evaluating NHP from different Brazilian biomes are much needed, in order to better understand the possible role of monkeys as hosts or reservoirs for Bartonella species. Besides, the use of a combinational approach consisting of pre-enrichment culture of Bartonella species in BAPGM (insect-based liquid culture medium), sub-inoculation of the liquid culture onto agar plates, followed by DNA amplification using PCR is desirable, since may facilitate the growth and detection of specific wild types of Bartonella, providing enhanced sensitivity [34,35]. Culture of specimens in BAPGM pre-enrichment medium enhanced the PCR detection rate of Bartonella species over that of direct nucleic acid extraction from blood specimens from dogs, horses and humans [36-40]. It is of clinical and epidemiological relevance that failure to amplify Bartonella sp. gene targets, following extraction of DNA from NHP blood samples, does not rule out this bloodstream infection. It is estimated that Bartonella bacteremia in asymptomatic donors is approximately $10 \mathrm{CFU} / \mathrm{mL}$ of blood [32], which may be below the detection limit of most conventional or Real-Time PCR assays. According to Harms and Dehio [41], another reason for false-negative PCR or culture results is that Bartonella spp. typically cause a cyclic bacteremia. Obtaining three sequential specimens during a 1-week period appears to enhance detection of Bartonella bacteremia in human patients and should be considered as a diagnostic approach when bartonellosis is suspected [35]. The knowledge of epidemiology of human and animal bartonellosis in northeastern Brazil is scarce yet, with only one report on B. henselae and B. clarridgeiae in domesticated and stray cats in São Luis Island [42].

The development of molecular assays primarily targeting the $16 \mathrm{~S}$ rRNA gene has resulted in the detection of a growing number of hemotropic mycoplasmas in animals and humans. These pathogens may have co-evolved with several animal species, including humans $[5,24,43,44]$. Some studies suggest that NHP may be susceptible to hemoplasma infection [12], showing mild to severe anemia $[10,11]$.

Previously, Mycoplasma sp. was detected in a free-ranging Alouatta caraya sampled in Paraná, Brazil, which was presented with normochromic and macrocytic anemia. BLASTn and phylogenetic analyses showed a low percentage of identity (93.6) and a clear separation from other sequences of 'Candidatus Mycoplasma kahanei' [15]. Herein, we reported for the first time the occurrence of hemoplasmas infecting neotropical primates from the Brazilian Amazon. The occurrence of Mycoplasma spp. in the evaluated NHP was lower [35.7\% (35/98)] than previously described in a study performed in the USA among NHP maintained in captivity in a research colony [84.6\% (44/52)] [3].

The phylogenetic analysis of 16S rRNA DNA sequences amplified from five Sapajus apella NHP's blood samples showed a strong separation from 'Candidatus Mycoplasma haemomacaque'. This finding was supported by a percentage of identity ranging from $95 \%$ to $97 \%$ with other primates hemoplasmas by Blast analysis, indicating the designation of possible novel hemoplasmas in NHP in Brazil.

Conversely, the 16S rRNA DNA sequences detected in two freeranging squirrel monkeys ( $S$. sciureus) were positioned in the same clade as 'Candidatus Mycoplasma kahanei', also detected in S. sciureus NHP in the USA [14]. This finding shows evidence that $S$. sciureus may play a role as hosts for 'Candidatus M. kahanei'.
However, future studies evaluating a larger number of animals are needed in order to better understanding the role of $S$. sciureus in the ecology of 'Candidatus M. kahanei'. Additionally, our results show the presence of more than one hemoplasmas species in neotropical NHP in Brazil.

\section{Conclusion}

The results of this study demonstrate that neotropical primates in the Brazilian Amazon can be infected, and may serve as reservoirs, of hemoplasmas, including a potential novel hemoplasma species.

\section{Acknowledgments}

We are grateful to Fundação de Amparo à Pesquisa do Estado de São Paulo (FAPESP) for the financial support to R.Z Machado (Process \#2010/12820-4) and for the Scientific Initiation Fellowship to L. Bonato (Process \#2014/25946-7).

\section{References}

[1] E.B. Breitschwerdt, Bartonellosis: one health perspectives for an emerging infectious disease, ILAR J. 55 (2014) 46-58.

[2] M. Vayssier-Taussat, J.F. Cosson, B. Degeilh, M. Eloit, A. Fontanet, S. Moutailler, D. Raoult, E. Sellal, M.N. Ungeheuer, P. Zylbermann, How a multidisciplinary 'One Health' approach can combat the tick-borne pathogen threat in Europe, Fut. Microbiol. 10 (2015) 809-818.

[3] R.G. Maggi, P.E. Mascarelli, N. Balakrishnan, C.M. Rohde, C.M. Kelly, L. Ramaiah, M.W. Leach, E.B. Breitschwerdt, "Candidatus Mycoplasma haemomacaque" and Bartonella quintana Bacteremia em Cynomolgus Monkeys, J. Clin. Microbiol. 51 (2013) 1408-1411.

[4] V. Jacomo, P.J. Kelly, D. Raoult, Natural history of Bartonella infections (an exception to Koch's postulate), Clin. Diagn. Lab. Immunol. 9 (2002) 8-18.

[5] A.P. dos Santos, R.P. dos Santos, A.W. Biondo, J.M. Dora, L.Z. Goldani, S.T. de Oliveira, et al., Hemoplasma infection in HIV-positive patient, Brazil, Emerg. Infect. Dis. 14 (2008) 1922-1924.

[6] J.B. Messick, Hemotrophic mycoplasmas (hemoplasmas): a review and new insights into pathogenic potential, Vet. Clin. Pathol. 33 (2004) 2-13.

[7] L.G. O'Rourke, C. Pitulle, B.C. Hegarty, S. Kraycirik, K.A. Killary, P. Grosenstein, J.W. Brown, E.B. Breitschwerdt, Bartonella quintana in cynomolgus monkey (Macaca fascicularis), Emerg. Infect. Dis. 11 (2005) 1931-1934.

[8] R. Huang, Q. Liu, G. Li, D. Li, X. Song, R.J. Birtles, F. Zhao, Bartonella quintana infections in captive monkeys, China, Emerg. Infect. Dis. 17 (2011) 1707-1709.

[9] H. Li, J.Y. Bai, L.Y. Wang, L. Zeng, Y.S. Shi, Z.L. Qiu, H.H. Ye, X.F. Zhang, Q.B. Lu, M. Kosoy, W. Liu, W.C. Cao, Genetic diversity of Bartonella quintana in macaques suggests zoonotic origin of trench fever, Mol. Ecol. 22 (2013) 2118-2127.

[10] J.E. Dillberger, D.E. Loudy, R.R. Adler, J.H. Gass, Haemobartonella-like parasites in cynomolgus monkeys (Macaca fascicularis), Vet. Pathol. 31 (1994) 301-307.

[11] H. Contamin, J.C. Michel, Haemobartonellosis in squirrel monkeys (Saimiri sciureus): antagonism between Haemobartonella sp. and experimental Plasmodium falciparum malaria, Exp. Parasitol. 91 (1999) 297-305.

[12] A. Barnaud, J.C. Michel, H. Contamin, Hemobartonellose latente chez le singe écureuil (Saimiri sciureus), primate du Nouveau-Monde: étude menée au Centre de Primatologie de l'Institut Pasteur de la Guyane, Rev. Med. Vet. 152 (2001) 863-870

[13] E.N. Barker, C.R. Helps, H. Neimark, I.R. Peters, W. Peters, S. Tasker, A novel haemoplasma species identified in archived primate blood smears, Vet. Microbiol. 149 (2011) 478-481.

[14] H. Neimark, A. Barnaud, P. Gounon, J.C. Michel, H. Contamin, The putative haemobartonella that influences Plasmodium falciparum parasitaemia in squirrel monkeys is a haemotrophic mycoplasma, Microbes Infect. 4 (2002) 693-698

[15] L.C. Santos, M.P. Cubilla, W. de Moraes, et al., Hemotropic Mycoplasma in a free-ranging Black Howler Monkey (Alouatta caraya) in Brazil, J. Wildl. Dis. 49 (2013) 728-731

[16] P. Perelman, W.E. Johnson, C. Roos, H.N. Seuánez, J.E. Horvath, M.A. Moreira, et al., A molecular phylogeny of living primates, PLoS Genet. 7 (2011) e1001342.

[17] M.A.P. Figueiredo, S.M.F. Di Santi, T.A.P. Figueiredo, R.Z. Machado, Natural Plasmodium infection in neotropical primates in the Island of São Luís, state of Maranhão, Brazil, Braz. J. Vet. Parasitol. 24 (2015) 122-128.

[18] A.J. Birkenheuer, M.G. Levy, E.B. Breitschwerdt, Development and evaluation of a semi-nested PCR for detection and differentiation of Babesia gibsoni (Asian genotype) and B. canis DNA in canine blood samples, J. Clin. Microbiol. 41 (2003) 4172-4177.

[19] M.R. André, J.S. Dumler, H.M. Herrera, L.R. Gonçalves, K.C. de Sousa, D.G. Scorpio, A.C. de Santis, I.H. Domingos, G.C. de Macedo, R.Z. Machado, Assessment of a quantitative $5^{\prime}$ nuclease real-time polymerase chain reaction 
using the nicotinamide adenine dinucleotide dehydrogenase gamma subunit (nuoG) for Bartonella species in domiciled and stray cats in Brazil, J. Feline Med. Surg. (2015), http://dx.doi.org/10.1177/1098612X15593787.

[20] S.A. Bustin, V. Benes, J.A. Garson, J. Hellemans, J. Huggett, M. Kubista, R. Mueller, T. Nolan, M.W. Pfaffl, G.L. Shipley, J. Vandesompele, C.T. Wittwer, The MIQE guidelines: minimum information for publication of quantitative real-time PCR experiments, Clin. Chem. 55 (2009) 611-622.

[21] A.F. Norman, R. Regnery, P. Jameson, C. Greene, D.C. Krause, Differentiation of Bartonella-like isolates at the species level by PCR-restriction fragment length polymorphism in the citrate synthase gene, J. Clin. Microbiol. 33 (1995) 1797-1803.

[22] R.J. Birtles, D. Raoult, Comparison of partial citrate synthase gene (gltA) sequences for phylogenetic analysis of Bartonella species, Int. J. Syst. Bacteriol. 46 (1996) 891-897.

[23] N.G. Miceli, F.A. Gavioli, L.R. Gonçalves, M.R. André, V.R. Sousa, K.C. Sousa, R.Z. Machado, Molecular detection of feline arthropod-borne pathogens in cats in Cuiabá, state of Mato Grosso, central-western region of Brazil, Rev. Bras. Parasitol. Vet. 22 (2013) 385-390.

[24] R.G. Maggi, M.C. Chitwood, S. Kennedy-Stoskopf, C.S. DePerno, Novel hemotropic Mycoplasma species in white-tailed deer (Odocoileus virginianus), Comp. Immunol. Microbiol. Infect. Dis. 36 (2013) 607-611.

[25] S.F. Altschul, W. Gish, W. Miller, E.W. Myers, D.J. Lipman, Basic local alignment search tool, J. Mol. Biol. 215 (1990) 403-410.

[26] J.D. Thompson, D.G. Higgins, T.J. Gibson, CLUSTAL W: improving the sensitivity of progressive multiple sequence alignment through sequence weighting, position specific gap penalties and weight matrix choice, Nucleic Acids Res. 22 (1994) 1673-4680.

[27] T.A. Hall, BioEdit: a user-friendly biological sequence alignment editor and analysis program for Windows 95/98/NT, Nucleic Acids Symp. Ser. 41 (1999) 95-98.

[28] A. Stamatakis, P. Hoover, J. Rougemont, A rapid bootstrap algorithm for the RAxML Web servers, Syst. Biol 57 (2008) 758-771.

[29] M.A. Miller, W. Pfeiffer, T. Schwartz, Creating the CIPRES Science Gateway for inference of large phylogenetic trees, in: Proceedings of the Gateway, Computing Environments Workshop (GCE), New Orleans, LA, 2010, pp. 1-8.

[30] H. Mooser, F. Weyer, Experimental infection of Macacus rhesus with Rickettsia quintana (trench fever), Proc. Soc. Exp. Biol. Med. 83 (1953) 699-701.

[31] P. Zhang, B.B. Chomel, M.K. Schau, et al., A family of variably expressed outer-membrane proteins (Vomp) mediates adhesion and auto-aggregation in Bartonella quintana, Proc. Natl. Acad. Sci. 101 (2004) 13630-13635

[32] E.B. Breitschwerdt, R.G. Maggi, B.B. Chomel, M.R. Lappin, Bartonellosis: an emerging infectious disease of zoonotic importance to animals and human beings, J. Vet. Emerg. Crit. Care 20 (2010) 8-30.
[33] L.H. Pitassi, P.P. de Paiva Diniz, D.G. Scorpio, M.R. Drummond, B.G. Lania, M.L. Barjas-Castro, R. Gilioli, S. Colombo, S. Sowy, E.B. Breitschwerdt, W.L. Nicholson, P.E. Velho, Bartonella spp. bacteremia in blood donors from Campinas, Brazil, PLoS Negl. Trop. Dis. 9 (1) (2015) e0003467, 2015.

[34] A.W. Duncan, R.G. Maggi, E.B. Breitschwerdt, A combined approach for the enhanced detection and isolation of Bartonella species in dog blood samples: pre-enrichment liquid culture followed by PCR and subculture onto agar plates, J. Microbiol. Methods 69 (2007) 273-281.

[35] E.L. Pultorak, R.G. Maggi, P.E. Mascarelli, E.B. Breitschwerdt, Serial testing from a 3-day collection period by use of the Bartonella Alphaproteobacteria growth medium platform may enhance the sensitivity of Bartonella species detection in bacteremic human patients, J. Clin. Microbiol. 51 (2013) 1673-1677

[36] N.A. Cherry, P.P.V.P. Diniz, R.G. Maggi, J.B. Hummel, E.M. Hardie, E.N. Behrend, E. Rozanski, M.B. Cadenas, E.B. Breitschwerdt, Isolation or molecular detection of Bartonella henselae and Bartonella vinsonii subsp. berkhoffii in idiopathic effusion samples obtained from dogs, J. Vet. Intern. Med. 23 (2009) 186-189.

[37] N.A. Cherry, S.L. Jones, R.G. Maggi, J.L. Davis, E.B. Breitschwerdt, Bartonella spp. infection in healthy and sick horses and foals from the southeastern United States, J. Vet. Intern. Med. 26 (2012) 1408-1412.

[38] P.P. Diniz, M. Wood, R.G. Maggi, S. Sontakke, M. Stepnik, E.B. Breitschwerdt Co-isolation of Bartonella henselae and Bartonella vinsonii subsp. berkhoffii from blood, joint and subcutaneous seroma fluids from two naturally infected dogs, Vet. Microbiol. 138 (2009) 368-372.

[39] R.G. Maggi, P.E. Mascarelli, E.L. Pultorak, B.C. Hegarty, J.M. Bradley, B.R. Mozaveni, E.B. Breitschwerdt, Bartonella spp. bacteremia in high-risk immunocompetent patients, Diagn. Microbiol. Infect. Dis. 71 (2011) 430-437.

[40] C. Pérez, R.G. Maggi, P.P. Diniz, E.B. Breitschwerdt, Molecular and serological diagnosis of Bartonella infection in 61 dogs from the United States, J. Vet. Intern. Med. 25 (2011) 805-810.

[41] A. Harms, C. Dehio, Intruders below the radar: molecular pathogenesis of Bartonella spp, Clin. Microbiol. Rev. 25 (2012) 42-78.

[42] M.S. Braga, P.P. Diniz, M.R. André, C.P. Bortoli, R.Z. Machado, Molecular characterisation of Bartonella species in cats from São Luís, state of Maranhão, north-eastern Brazil, Mem. Inst. Oswaldo Cruz 107 (2013) 772-777.

[43] S. Hornok, G. Foldvári, K. Rigó, M.L. Meli, E. Gonczi, A. Répási, R. Farkas, I. Papp, J. Kontschán, R. Holfmann-Lehmann, Synantropic rodents and their ectoparasites as carriers of a novel haemoplasma and vector-borne, zoonotic pathogens indoors, Parasites Vectors 8 (2015) 8-27.

[44] J.E. Sykes, Feline hemotropic mycoplasmas, J. Vet. Emerg. Crit. Care 20 (2010) 62-69. 